\title{
Does Recruitment Develop a Corporate Image to Attract Talented Candidates for Hiring in Bangladesh?
}

\author{
Rumana Afroze \\ Sr. Lecturer (HRM), Department of Business Administration, East West University, A/2, Jahurul Islam Avenue, Aftabnagar, Dhaka 1212, \\ BANGLADESH \\ E-mail for correspondence: rua@ewubd.edu
}

\begin{abstract}
Recruitment is one of the major functions of Human Resource Management (HRM) which is the process of attracting qualified candidates. Recruitment depends on some factors like recruitment cost, budget and sources of recruitment, etc. This study finds out how job advertisement and other recruitment methods develop corporate image and then it reveals how developed corporate image influence, talented candidates, to apply for the job. This study is a predominantly qualitative nature and presents study findings through the in-depth interview methods. Purposive sampling has used for selecting respondents. Respondents are potential candidates like fresh graduates, final year students, new employees as well as expert HR personnel. The study found that most of the candidates prefer multinational companies as well as reputed local organization to join because of their positive images. Respondents believe that employees of these companies are getting more facilities, more advancement and higher pay and benefits. Moreover, talent candidates also get information about the company from different job advertisement. Organization tries to create an attractive job advertisement by mentioning some information like salary structure, facilities, benefits, working environment and so on. This information mainly influences the candidate's intention for applying in the organizations. In addition to this, new organizations often prefer to participate in the job fair and different career seminar for creating a positive company image. Their target is to influence the talent candidates for applying in their organization.
\end{abstract}

Keywords: Recruitment, corporate image, candidate's intention

\section{INTRODUCTION}

Recruitment and selection are important human resource functions especially managerial post. Recruitment and selection can maintain a sustainable competitive advantage than the other competitors (Judge and Ferris, 1994).

Executive recruitments has an impact on an organization's success or failure. To remain competitive organization must be able to attract and retain the most qualified leaders and employees. Today's executive must be capable of increasing productivity, innovation, leadership and supervisory adaptability (Souza and Zagas, 1995). The effectiveness of an executive affects both the functional area and the overall company. For recruiting and selecting team player/top managers, Evaluators must be considered technical skills, managerial skills and also ensure the candidates' match with organizational values and job position (Souza and Zagas, 1995). Effective recruiting and selection are reduced labor turnover whereas ineffective recruiting is costly for the organizations.

Traditional perspective on recruitment and selection was focus on requirements of the job. But now organization is also focused on real knowledge about job, applicant's job relevant qualifications that can match with job demand and also fit with organization's goals and values (Judge and Ferris, 1994). So organizations need to focus on the fit between personality, traits, beliefs of candidate's and values with the culture, strategic needs, norms and values of the organization.

\section{Meaning of Recruitment}

Recruitment is the process of seeking sources for job candidates; Recruiting is the process of discovering potential for actual on anticipated organization's vacancies (Robbins, Coutler and Vohra, 2010). Recruitment is also the process of finding and attracting applicants for the employer's open position. Recruiting employees can be a challenging task so that recruiters have to make important decisions, including whom to target, what message to convey and how to staff recruitment efforts. An incorrect organization's recruitment efforts can produce job applicants who are unqualified, who lack diversity or who may decline job offers. 
According to Bhat and Kumma (2010) "Recruitment is a specialized task, effective recruitment is becoming more and more important and challenging in the present business environment. Effective recruitment contributes a great deal to the organizational goal." Recruitment is a challenging work because of Success of recruitment is also dependent on the recruitment policies and non-recruitment issues. Recruitment is based on employment law that prescribed what organization can / can't do (Dessler, 2011).

There are some steps of effective recruitment. These are Identifying the existence of a vacancy, Identifying a pool of appropriate candidates, the Selection process, selection tests \& interview techniques, the criteria for recruiting candidates, the job offer letter and Induction of selected employees (Bhat and Kumma, 2010). Moreover, organizations have been used different recruitment and selection techniques for different jobs. Like managerial recruitment techniques are different from other manual workers job (Hsu and Leat, 2000). Harris, Brewster and Sparrow (2003) identified three main areas that can create differences in recruitment practices. These are labor legislation, internal/external labor market, and recruitment sources.

\section{Corporate Image}

Some others related terms of the corporate image are organizational image/brand image/Corporate brand/ reputation of the company and so on. An organizational image refers as an overall impression that is based on facts, beliefs, and feelings about an organization. Corporate branding is not like to attract customers, but to appeal to potential employees. An employer brand provides job applicants with a realistic image of what it would be like to work in a particular company. It includes all the factors that make the company a good place to work. These might include: bright and cheerful office space, collaboration in team work, flexible working hours and so on. These factors can influence employment choices.

\section{Recruitment Strategies}

One of the objectives of effective recruitment is to develop recruitment strategies. The organizational website is one of the recruitment methods that reflect the three attributes: navigability, aesthetic features, and employment content information. Web site's aesthetic features and employment content information are positively associated with organizational attraction (Brian and Janet, 2011). Another objective of recruitment is to create recruitment brand. There are some outcomes of Recruitment Brand. These are hiring the right people, increased organization's Reputation, Increased number of qualified candidates, Lower turnover, and increased number of diverse candidates, higher job candidate job offer acceptance rate and Open positions filled more rapidly. According to Terpstra (1996) when the organization is going to downsize then they try to boost productivity with fewer people. They want employees who know more and do more and change more and interact more. So it is important to identify the recruiting sources that can identify high-quality employees. It is a very critical concern for the organization to hire and promote the best-qualified people. For attracting qualified people, corporate image has been played an important role. And recruitment has also played an important role in developing a corporate image.

\section{LITERATURE REVIEW}

There are some important issues in the recruitment process. These are spending appropriate time for the recruitment process, Flexible patterns of employment - part-time, standby staff, etc. Recruitment should be consistent with training and career development, Recruit staff for long-term organizational needs. Negotiate expectations about autonomy and responsibility at the recruitment stage; Discuss issues of organizational culture and style at recruitment. Recruit for organizational breadth and diversity (Richard, 1994). Informal recruitment practices and inappropriate selection can lead to high labor turnover so that organization should maintain the employment law. If an organization does not follow the employment law properly, that will cause recruiting inappropriate people. This study also suggests that small firms should recruit from the local labor market and also should keep their recruitment spending within their budget (Stephanie, 2000).

Boxall and Purcel (2003) observed in their study that many organizations still imagine that recruitment is all about attracting young workers from schools or after only a few years in the labor market. However, according to Pilbeam and Corbridge (2002), recruitment and selection cover attracting suitable candidates, eliminating unfitting candidates and transforming the successful candidates to an effective employee.

In addition to these above-mentioned factors, an organizational image is important for effectively manage potential recruits. For an organizational image, employees' can play a central role. In recruitment process, employees' views and behavior are influence the candidates' image about organizations. For ensuring diversity in workplace, gender is an important issue. For recruiting female candidates, the organization needs to know their preferences. Female candidates mainly prefer an organization that are careful about employees and want to treat them equally (Chenyl,2003).

There are some negative things on the recruitment that can limit recruitment outcomes such as corporate image, internal organizational policies, govt. Influence and recruiting cost. For example, poor image of the organization may limit its attraction to the applicant. Job attraction is also an important factor. If the vacant job is unattractive, then it is difficult to attract a qualified pool of candidates. (Maud, 1996). 


\section{ObJectives of the Study}

This study finds out

- How corporate images developed through job advertisement and other recruitment methods

- How does corporate image influences talent candidates intention to apply for a job

\section{Methodology of the Study}

This study is a predominantly qualitative nature and Indepth interview has been taken. Purposive sampling has been used for selecting respondents. Respondents are potential candidates like final year students, new employees as well as expert HR personnel.

\section{Findings AND ANALYsis OF THE Study}

\section{Interview 1}

HR personnel were asked some questions. This study found the following findings from HR personnel

Table 1: Findings from HR personnel

\begin{tabular}{|c|c|}
\hline $\begin{array}{l}\text { Question 1 } \\
\text { How does } \\
\text { organization } \\
\text { develop HR } \\
\text { branding? }\end{array}$ & $\begin{array}{l}\text { Our Organization has developed Hr } \\
\text { Branding (both External and Internal). (R1) } \\
\text { It has created external branding by } \\
\text { Organizing Job Fair and Career Seminar } \\
\text { to the Different Universities and also } \\
\text { provides job contents information to the } \\
\text { job advertisement. (R1) } \\
\text { It has also created Internal Branding } \\
\text { through Discussion about employee's } \\
\text { possible reasons of dissatisfaction. Also } \\
\text { provided good salary, a good working } \\
\text { environment, other facilities and } \\
\text { different kinds of discount facilities to } \\
\text { the employees. (R1) }\end{array}$ \\
\hline $\begin{array}{l}\text { Question } 2 \\
\text { How does } \\
\text { Recruitment } \\
\text { develop } \\
\text { Corporate } \\
\text { Image? }\end{array}$ & $\begin{array}{l}\text { Organization has written recruitment } \\
\text { policies. (R1) } \\
\text { It has also developed recruitment } \\
\text { strategies for attracting candidates. (R1). } \\
\text { New organizations participated } \\
\text { different job Fair for a creating positive } \\
\text { image and finally influenced talented } \\
\text { candidates. (R1) } \\
\text { Our company has a requisition form for } \\
\text { a vacant and new position. Labor law } \\
\text { and External Policy are taken into } \\
\text { account as legislative requirements } \\
\text { when recruiting. Job descriptions are } \\
\text { reviewed monthly. Our organization } \\
\text { has a website, and that is used for } \\
\text { recruitment. (R2) } \\
\text { Our company has a written policy } \\
\text { regarding internal recruitment versus } \\
\text { external recruitment like } 65 \% \text { Internal } \\
\text { versus } 35 \% \text { external. (R2) } \\
\text { Our company takes into account } \\
\text { legislative requirements when recruiting. } \\
\text { Our company uses written job description } \\
\text { and duty statement. A Job description has }\end{array}$ \\
\hline
\end{tabular}

reviewed as position becomes vacant. The organization has a website and it is used for recruitment. Newspaper, the Internet, Referrals, University Notice Boards. Words of Mouth, Employment Consultant, Recruitment Agency have used as a source for recruitment for giving an advertisement for a position. The company has its own applicant form(R3)

- Our company has a written policy regarding internal recruitment versus external recruitment. From the last five positions filled, $10 \%$ Internal versus $90 \%$ external. The company uses employment consultants rarely. The company uses recruitment agencies as per requirement. (R3)

Organization tried to attract qualified employees through recruitment policies, practices and Hr branding. By Internal and external branding, developed corporate image can attract qualified candidates

\section{Interview 2}

This study also found the following findings from the existing employees. Most of them said that company reputation influenced them most for choosing the current employer. They also said some other factors. These are shown in Table 2.

Table 2: Findings from Current Employees

\begin{tabular}{|c|c|}
\hline $\begin{array}{l}\text { Question } 1 \\
\text { Why are you } \\
\text { choosing } \\
\text { your current } \\
\text { organization? }\end{array}$ & $\begin{array}{l}\text { We are choosing our current organization } \\
\text { because of the following reasons } \\
\text { Reputation } \\
\text { position of the company/Market Leader } \\
\text { Career growth } \\
\text { Good salary } \\
\text { Innovative company } \\
\text { Size of the company } \\
\text { Comfortable Environment } \\
\text { better customer service } \\
\text { Job security } \\
\text { Dultinational company } \\
\text { Friendly organization } \\
\text { Better working Environment } \\
\text { (R3, R4, R5, R6, R7, R8,R9, R10, R11, R12) }\end{array}$ \\
\hline $\begin{array}{l}\text { Question } 2 \\
\text { How did you } \\
\text { get the } \\
\text { information } \\
\text { about the } \\
\text { current } \\
\text { employer? }\end{array}$ & $\begin{array}{l}\text { Friends and Colleagues (Internal } \\
\text { branding) } \\
\text { Job Advertisement (External branding) } \\
\text { Jobs-sites (External branding) } \\
\text { Websites(External branding) } \\
\text { Wews paper(External branding } \\
\text { (R3, R4, R5, R6, R7, R8,R9, R10, R11, R12) }\end{array}$ \\
\hline
\end{tabular}

From the above-mentioned table it has been said that internal hr branding makes the employees satisfied. And external branding attracts the qualified candidates. Present study found that company reputation has been played an important role for attracting candidates. 


\section{Interview 3}

Freshers were also asked some questions. This study found the following findings

\begin{tabular}{|c|c|}
\hline $\begin{array}{l}\text { Question } 1 \\
\text { What types } \\
\text { of } \\
\text { organization } \\
\text { do you } \\
\text { prefer and } \\
\text { why? }\end{array}$ & $\begin{array}{l}\text { We want to be banker } \\
\text { We want to get a job in the } \\
\text { multinational companies } \\
\text { We are searching for opportunities to the } \\
\text { well reputed local and multinational } \\
\text { companies. Because these organizations } \\
\text { provide lots of opportunities for the } \\
\text { employees and their salary structure is } \\
\text { also high. } \\
\text { (R14, R15, R16, R17, R18,R19, R20, R21, R22, } \\
\mathrm{R} 23, \mathrm{R} 24, \mathrm{R} 25, \mathrm{R} 26, \mathrm{R} 27, \mathrm{R} 28, \mathrm{R} 29, \mathrm{R} 30)\end{array}$ \\
\hline $\begin{array}{l}\text { Question } 2 \\
\text { How did } \\
\text { you get the } \\
\text { information } \\
\text { about the } \\
\text { current } \\
\text { employer? }\end{array}$ & $\begin{array}{l}\text { We got the information about } \\
\text { companies from our relatives, friends } \\
\text { and our seniors (Internal branding) and } \\
\text { from job advertisement, Job fair and } \\
\text { career seminar (external branding) } \\
\text { (R14, R15, R16, R17, R18,R19, R20, R21, R22, } \\
\text { R23, R24, R25, R26, R27, R28, R29, R30) }\end{array}$ \\
\hline
\end{tabular}

From this, it has been said that corporate image influence fresher's and last year's students. They prefer MNCs and reputed banks because of their salary structure, flexibility, and other benefits. They have got the information from job advertisement and also from their relatives and friends. These are the part of hr branding.

\section{DISCUSSIONS AND IMPLICATIONS}

So It has been said that the positive corporate image influence the potential candidate's intention to apply for a job. Through recruitment organizations tried to develop a corporate image. Organizations use different methods of recruitment like job advertisement in their web site, newspaper and other job sites. Through Job contents, they also tried to develop a corporate image that finally influences the perception of talented candidates. One of the important objectives of recruitment is to develop Recruitment brand and also should publicized properly. Organization can establish the values in recruitment that match with the organization. And finally communicate organizational brand through these following ways -highlight the brand on their web site, describe it in recruitment literature or sponsor college campus events and so on.

\section{REFERENCES}

Bhat A. and Kumma A. (2010) Management Principles, Process and Practices, OUP India.

Boxall. P \& Purcell. J. (2003), Strategy and Human Resource Management, Palgrave Macmillan, New York.

Brian D. Lyons Janet H. Marler, (2011),"Got image? Examining organizational image in web recruitment", Journal of Managerial Psychology, Vol. 26 Iss 1 pp. 58 - 76.

Cheryl Freeman, (2003),"Recruiting for diversity", Women in Management Review, Vol. 18 Iss 1/2 pp. 68 - 76

Dessler Gary and Varkkey Biju (2011) “ Human Resource Management" Pearson

Francesca Spinelli Souza Jay J. Zajas, (1995),"Recruiting executives in business:", Executive Development, Vol. 8 Iss 3 pp. 23 - 27

Harris, H., Brewster, C. and Sparrow, P. (2003), International Human Resource Management, CIPD, London.

Hsu, Y. and Leat, M. (2000), "A study of HRM and recruitment and selection policies and practices in Taiwan", International Journal of Human Resource Management, Vol. 11 No. 2, pp. 413-35.

Judge , T. and Ferris , G. (1994) " The elusive criterion of fit in Human Resources staffing decision" Human Resource Planning, Vol. 15 No. 4 pp. 47-66

Maud Tixier, (1996),"Employers' recruitment tools across Europe", Employee Relations, Vol. 18 Iss 6 pp. $69-80$

Muller-Camen, M., Croucher, R. \& Leigh, S. (2008). Human Resource Management: A Case Study Approach. London, UK: Chartered Institute of Personnel and Development

Pilbeam. S \& Corbridge S, (2002), "People Resourcing HRM in Practice, 2/e, Pearson Education Ltd. UK.

Richard Lee, (1994),"Recruitment in Context", Librarian Career Development, Vol. 2 Iss 2 pp. 3 - 7

Stephanie M. Jameson, (2000),"Recruitment and training in small firms", Journal of European Industrial Training, Vol. 24 Iss 1 pp. $43-49$

Stephen P. Robbins and Mary Coutler and Neharika Vohra (2010) "Management" Pearson Prentice Hall

Terpstra, D. (1996) " The search for effective methods (employee recruitment and selection)' HR Focus, vol. 17 No. 5 pp. 16-18

-- 0 --

\section{APPENDIX}

Demographic Information about Respondents

\begin{tabular}{|l|l|l|}
\hline Respondents of Interview 1 & Respondents of Interview 2 & Respondents of Interview 3 \\
\hline Hr personnel (R1) & Employee (R2 to R11) & Students (R14 to R30) \\
\hline R1: Sr. Executive HR and & R4: Principal Officer of South East Bank Limited & \\
Admin of Banglalink & R5: Lecturer in Jahangirnagar University & (R14, R15, R16, R17, R18,R19, R20, \\
& R6: Principal Officer of Mercantile Bank limited & R21, R22, R23, R24, R25, R26, R27, \\
R2: Senior Vice President & R7: Operation Manager of MGH group & R28, R29, R30) \\
Prime bank limited & R8:Assistant Manager of Citibank N.A & \\
& R9: Trade Marketing Manager of Philip Morris & \\
R3: HR Executive & International & \\
ACI Pharmaceuticals Limited & R10:Principal Officer of Sonali bank limited & \\
& R11: Senior Lecturer in East West University & \\
& R12: Senior Lecturer in East West University & \\
& R13: Senior officer of Sonali bank limited & \\
\hline
\end{tabular}

